\title{
Collaborative Writing and Peer Feedback Practices Using Google Docs
}

\author{
Ika Lestari Damayanti, Nur Hafiz Abdurahman, Lala Wulandari* \\ Department of English Education, Universitas Pendidikan Indonesia, Bandung, Indonesia \\ *Corresponding author. Email: lalawulandari94@gmail.com
}

\begin{abstract}
This paper explored how six senior high school students can be supported to write collaboratively using Google Docs. It also identified types of feedback provided by the students during the collaborative writing activities. The present study employed case study involving six students. The data were collected through interviews, the students' chat room discussion, and their peer feedback practices in Google Docs. Students' feedback analysis was adopted from Weigle's (2002) writing rubric and Widarsih and Suherdi's feedback analysis (2019). The discussion was then coded according to students' discussion when generating idea, organizing the text, and revising their texts. The results of the study indicated that the use of Google Docs supported the students' collaborative writing and peer feedback practices. Features available in Google Docs that were frequently used by the students are chat room and comment. These features were particularly useful for generating ideas, organizing the text structure, and constructing sentences.
\end{abstract}

Keywords: Collaborative writing, Google Docs, peer feedback

\section{INTRODUCTION}

In learning English, many EFL students find it difficult to master English language skills, especially in English writing for both academic and general purposes (e.g., Dastgeer \& Afzal, 2015; Younes \& Albalawi, 2015). Producing coherent, fluent, comprehensive writing may become one of the most challenging language learning tasks. Many methods to overcome such problems have been proposed. Alwasilah (2001), for example, suggested collaborative writing as an alternative way to assist students to develop their writing skills. Through collaborative writing, students can work and learn from each other through mutual feedback. Likewise, Widodo (2013) reported that reciprocal assistance through peer feedback improved students' linguistic repertoire by sharing knowledge and linguistic resources, negotiating with others, and creating a joint product. As a form of collaborative learning, peer feedback can be an effective pedagogical activity in improving teaching and learning of second language writing (Bijami, Kashef, \& Nejad, 2013; Min, 2005; Yu \& Lee, 2015).

While these studies reported on the virtues of collaborative writing in 'traditional' classroom contexts, studies investigating collaborative writing during the COVID-19 pandemic are scarce. It is widely acknowledged that due to the pandemic, all schools and universities are closed to slow the COVID-19 spread (World Health Organization, 2020). In response to this current situation, the Indonesian Government has decided to close all schools and universities in Indonesia and changed the learning system practices into an online learning system. Therefore, in the current situation, the teachers should adjust their learning practices to online platforms, to facilitate the teaching and learning activities virtually from home.

Myriad of online platforms can assist teachers during online learning practices. One of them is Google Docs, which is accessible in Indonesia. Alharbi (2019) indicated that Google Docs could facilitate writing instructional practices, especially for collaborative writing activities. Google Docs allows people to work, read, review, comment, and edit to each other in the same document simultaneously (Deveci, 2018; Ishtaiwa \& Aburazeq, 2015). Given the perpetual benefits that Google Docs offers, this study reported in the paper sought to explore students' interactions and peer feedback practices during the collaborative writing processes using Google Docs, especially in generating their ideas, organizing the text, and constructing the sentences. 


\subsection{Literature Review}

\subsubsection{Collaborative Writing}

Collaborative writing is an activity in which students work collaboratively in producing a single paper (Howard, 2001). Collaborative writing is also defined as an activity to produce a text conducted by two or more people (Storch, 2011). From both definitions, collaborative writing can be defined as an activity involving two or more students working together to produce a single text. The students are encouraged to collaborate throughout the writing processes.

The collaborative writing activity is often implemented in the second language classroom to promote an interactive classroom atmosphere (Storch, 2013). As an instructive and interactive activity, collaborative writing has been increasingly adopted in the second language (L2) classrooms over the past decades (e.g., Dobao, 2012; Storch, 2005; Wigglesworth \& Storch, 2012). A number of studies investigating collaborative writing practices in L2 classrooms reported that collaborative writing tasks are beneficial in a way that they offer more learning opportunities such as reading and discussions among the students, leading to better learning outcomes ( $\mathrm{Li} \& \mathrm{Zhu}, 2017$; Zhang, 2018).

Collaborative writing activity is informed by the social constructivist theory of learning Vygotsky's theory (1978) that learning is a social activity. In other words, the learning process is not an individual activity, but it is a cognitive activity that turns the focus of learning from an individual context to an interaction within a social context (Fung, 2010). Therefore, the students develop knowledge through the social interaction processes with others. As in collaborative writing, the students work together in two or more students to share knowledge and linguistic resources, negotiate with others and create a joint product (Widodo, 2013). Likewise, Chen (2014) states that through collaborative learning, learning and knowledge are made socially through communication and interaction among the students in a community.

Collaborative writing processes involve a series of writing stages such as prewriting, drafting, responding, revising, and editing (Mulligan \& Garofalo, 2011; Shehadeh, 2011; Storch, 2005; Widodo, 2013). The writing processes include the followings. 1) Prewriting as the beginning part of the writing stages involves forming the group, teacher's support, and generating ideas. Forming the group can be done based on the teacher's decision, students' preferences, genders, students' proficiency levels, interest, and the topic. Strategies in generating ideas can include reading (extensively) a passage, skimming and scanning a passage, conducting some research, brainstorming, listing, clustering, discussing a topic or questions, instructor-initiated questions and probes, and freewriting (Brown, 2000). 2) Drafting aims to support students to develop their ideas collaboratively into an iterative cycle of drafting with less concern on linguistic components such as vocabulary and grammar. 3) Responding is a stage in which both the teacher and peers provide feedback or comments on students' works regarding the content (ideas), rhetorical organization, and language form (vocabulary and grammar). 4) Revising and editing allows the students to rewrite their draft based on the feedback they received.

\subsubsection{Peer Feedback}

In the educational context, feedback is defined as information given to students of how successfully the projects have been or are being conducted (Sadler, 1989). Over the past twenty years, writing pedagogy and research have proposed a variety of feedback practices. Hyland (2006), for example, highlights that teachers' written feedback is often supplemented by peer feedback, workshops of writing, conferences, and even computer-mediated feedback. In a similar vein, Khalil (2018) underscores the importance of peer feedback in addition to the teachers. Peer feedback, also known as peer evaluation, peer response, peer editing, and peer review, is considered as one of the essential tools in enhancing the process of language learning, especially in writing (Bijami, Kashef, \& Nejad, 2013, Tsui \& Ng, 2000). It has been pedagogically determined as one of the effective methods to improve students' writing skill performances (Farrah, 2012).

Peer feedback plays an important role in collaborative learning activities (Wakabayashi, 2016). The students work together to provide and share their opinions on one another's drafts in both written and oral formats to improve their writing skills (Farrah, 2012). The process of peer feedback practices enhances the students' awareness of their own mistakes by reading their peers' writing assignments (Tsui \& Ng, 2000).

Feedback is divided into two types, such as direct feedback and indirect feedback (Bitchener \& Ferris, 2012). In direct feedback, the teachers not only mark the wrong sentences on the text, but they also provide the feedback along with some suggestions or examples of its correct form. Indirect feedback refers to the teacher giving feedback without telling or suggesting the correct one.

Direct feedback is categorized into four categories, such as deletion, insertion, substitution, and reformulation (Widarsih \& Suherdi, 2019). Deletion is a technique of giving feedback that removes a wrong word in the text. Insertion is inserting the correct word in a text or sentence that is considered incomplete. Substitution is replacing a wrong word with a correct word. Reformulation is rewriting the wrong part of the 
text and giving it suggestions to write it in the correct form.

Indirect feedback is categorized into three categories, namely coded feedback, uncoded feedback, and commentary (Widarsih \& Suherdi, 2019). Coded feedback is when the teachers mark the identified errors with certain codes, for example, 'ss' (sentence structure), 'ww' (wrong word), 'vt' (verb tense errors). In the uncoded feedback, the teachers mark the wrong sentences with the symbols ',' above the identified errors. Commentary is referred to the teachers' comments on what students have written about and several instructions for the students to improve their writing.

Focus of feedback can include content, organization, vocabulary, language use, and mechanics (Weigle, 2002). Content refers to the writing substance related to the idea's unity. Organization refers to the logical flow of ideas, text and paragraph structures. Vocabulary refers to the word selection relevant with the content and topic. Language use deals with the use of correct grammar. Mechanics refers to the writing conventions governing the writing technical aspects such as punctuation, spelling, capitalization, and abbreviation.

\subsubsection{Google Docs}

The development of computers and expanded internet connection accessibility have contributed to the emergence of various resources to facilitate collaborative writing practices. The development of online technologies web 2.0, including wikis, blogs, Google Docs, and another online forum, provides authors, particularly teachers and students in the educational context, with modern interactive technologies for collaborative writing practices (Limbu \& Markauskaite, 2015). Online technologies and environments have provided new opportunities to develop knowledge through interaction virtually during the writing processes (Nykopp, Marttunen, \& Erkens, 2018). Those platforms are designed to be highly interactive and collaborative, offering the virtual space for numerous authors to develop joint texts (Hadjerrouit, 2011). However, those technologies alone cannot promote a good learning activity without assistance from the entire learning ecology. It means that the success and learning improvements not only rely on those technologies themselves, but also the entire learning ecology (Limbu \& Markauskaite, 2015). Thus, the students' participation in performing and coordinating with their group has a vital role in the success of online collaborative writing practices (Janssen et al., 2012).

In recent decades, the technology of Web 2.0 has developed many useful internet services and programs such as blogs, wikis, and Google (Suwantarathip \& Wichadee, 2014). In the EFL learning contexts, the applications of Web 2.0 tools, specifically Google Docs, have the potential to be used by the teachers to create an interactive learning environment for students' group works (Alharbi, 2019). Google Docs is one of the Google features used as a teaching and learning media for collaborative writing (Metilia \& Fitrawati, 2018). It allows the users to work collaboratively, edit, and save their works to the server automatically (Thompson, 2008).

A number of studies investigating the use of Google Docs indicate that the application can facilitate students' collaborative writing and peer feedback practices. For example, a study by Alharbi (2019) involving university students suggests that Google Docs is one of the tools that support students to improve their writing skills through collaborative writing. In the Indonesian context, Metilia and Fitrawati's (2018) research showed that Google Docs allows students to interact and work together with other students to develop their writing skills. Similarly, Ebadi and Rahimi (2017) found that the use of Google Docs in collaborative writing activity provides the learners with the opportunities to read, review, comment, and edit each other's work. Through such interactions during the writing process, the students have opportunities to learn about four areas of academic writing such as task achievement, coherence and cohesion, lexicon, and grammatical accuracy.

As far as students' perceptions are concerned, a study by Suwantarathip and Wichadee (2014) indicates the students' positive attitudes toward the use of Google Docs in a collaborative writing activity. The students in Wahyuni's (2018) study reported their positive appreciation that they felt comfortable in using Google Docs as interactive learning media for collaborative writing activities. In sum, students' positive point of view of Google Docs can be considered as a supporting aspect for incorporation of the application into writing activities.

Despite the perceived benefits of Google Docs for collaborative writing, the students may face several challenges (Alharbi, 2019; Ishtaiwa \& Aburezeq, 2015). These include slow internet connection, formatting features in the Google Docs, and the ability to use the application (Alharbi, 2019). In addition, Ishtaiwa and Aburezeq (2015) highlighted several factors limiting the students' collaboration in using Google Docs, such as students' lack of teamwork skills and technological skills, discomfort with the editing tools, and preference to use other collaborative tools. Given the identified challenges, pedagogical practices wishing to use Google Docs as part of collaborative writing practices requires anticipated actions, which will be taken into consideration by the current study reported in this paper. 


\section{METHOD}

Table 1. Types of Students' Feedback

\begin{tabular}{ll}
\hline \multicolumn{1}{c}{ Type of Feedback } & \multicolumn{1}{c}{ Definitions } \\
\hline $\begin{array}{l}\text { Direct Feedback } \\
\text { Insertion }\end{array}$ & Insertion is inserting the correct word in a text or sentence that is considered incomplete. \\
$\begin{array}{l}\text { Substitution } \\
\text { Deletion }\end{array}$ & $\begin{array}{l}\text { Substitution is replacing a wrong word with a correct word. } \\
\text { It is a technique of giving feedback that removes a wrong word in the text. } \\
\text { Reformulation } \\
\text { correct form. }\end{array}$ \\
$\begin{array}{l}\text { Indirect Feedback } \\
\text { Coded }\end{array}$ & $\begin{array}{l}\text { Coded feedback is a kind of giving feedback with the code. } \\
\text { Uncoded } \\
\begin{array}{l}\text { Commentary } \\
\text { Instruction }\end{array}\end{array}$ \\
\hline
\end{tabular}

(Source: Widarsih \& Suherdi, 2019)

Table 2. Writing Rubric

\begin{tabular}{ll}
\hline \multicolumn{1}{c}{ Writing Aspect } & \multicolumn{1}{c}{ Criteria } \\
\hline Content & $\begin{array}{l}\text { The content is knowledgeable, substantive, thorough, development of topic sentence, relevant to } \\
\text { assigned topic. }\end{array}$ \\
It deals with the fluent expression, ideas clearly stated/supported, succinct, well-organized, logical \\
Sequencing, cohesive.
\end{tabular}

(Source: Weigle, 2002)

This case study aimed to explore how six senior high school students can be supported to write collaboratively using Google Docs and identify types of feedback provided by students during the collaborative writing activities. Particularly, the feedback was identified in terms of its contribution in generating ideas, organizing the text, and constructing the sentences. The lessons were conducted in five face-toface meetings by observing the COVID-19 Health Protocol. One of the authors was the teacher in this program who on the first meeting of the class introduced the materials to be covered throughout the program. A pre-program test for the students was also administered on the first meeting in order to identify the students' initial writing skills.

Participants of the study were recruited using snowball sampling to reach potential participants who suit the intended characteristics using the researchers' social networking in a multistage process (Sadler, 2010). The snowball sampling technique is used in this study due to the difficulties in accessing the participants in the school since all of the schools, especially in the West Java area, are temporarily closed due to the COVID-19 pandemic outbreak.
The data were collected from interviews, students' chat room discussions, and students' peer feedback in Google Docs. The data were analysed through three steps adopted from Creswell (2012), such as: preparing and organizing the data, reducing the data, and representing the data. Firstly, the data from the interview were transcribed. Following this, the transcript and students' chat were coded and categorized, which were reduced into smaller parts. The pattern and theme were developed by integrating the code and categorization from different participants.

In terms of analysis of feedback, a framework adopted from Widarsih and Suherdi (2019) was used in this study to identify types of feedback provided by the students (see Table 1). In addition, a writing rubric developed by Weigle (2002) was used as a guideline for the students to provide feedback for their peers (see Table 2)

\section{FINDINGS AND DISCUSSIONS}

\subsection{Collaborative Writing Practices using Google Docs}

The first issue investigated in this study dealt with the ways the students write collaboratively using Google 
Docs, especially when they are generating the ideas, organizing the structure of the text, and constructing the sentences.

The analysis of the interview data indicated a number of strategies the students used in generating ideas when using Google Docs. The most commonly reported strategies are brainstorming the topic, exploring related sources using an available feature connected directly to Google Search, and exchanging students' experiences. This finding supports Brown's (2000) arguments that generating ideas can be done better through collaboration. Likewise, Deveci (2018) reports that sharing processes with other leads not only to the development of innovative and fresh ideas, but also to make the writing task more creative and comfortable.

It was noticeable that Google Docs features frequently used by the students in peer feedback practices is the comment box and chat room. The students used the comment feature to make commentaries on the particular words or statements in the text.

The data analysis also indicates that the chat room feature in Google Docs allowed the students to talk about their experiences relevant to their writing topic. For example, they discussed whether they had visited the place that they were going to describe in their joint text. It was noticeable that the chat room feature allows students to chat in the file at the same time (Google Support, 2020). It resonates with the study conducted by Alharbi (2019) which revealed that Google Docs with the affordances of its chat room has a potential to create an interactive learning environment for students' group work.

While the chat room was useful for students' collaboration, the feature can only be accessed through a PC or laptop as it is not yet accessible in the mobile application both in Android and IOS (Google Support, 2020). To compensate for limited access to interaction, the participant students used WhatsApp on their mobile phone because most of them used the mobile application of Google Docs.

In terms of how students organized the text, the participant students initially made an outline of the text that included an introductory paragraph, supporting paragraphs, and a concluding paragraph. Following the outlining, the students determined the main idea of each paragraph. Then, they negotiated the distribution of paragraph development with the group members. At sentence level, it was observable that the participant students constructed the sentences by using Bahasa Indonesia and then translating them, word by word using a dictionary. From the students' perspectives, Google Docs was fun and facilitated them for collaborative writing practices. They felt comfortable as it allowed them to work online collaboratively on the same file with others without face-to-face meeting. It is in line with the result of the study by Wahyuni (2018), which revealed that the students' responses towards the collaborative writing practices using technology such as Google Docs are positive as they are comfortable using this interactive learning technology. Nykopp, Marttunen, and Erkens (2018) also mentioned that the online technologies such as Google Docs provides an opportunity for students to develop knowledge through interaction virtually during the writing processes.

The participant students also reported that the peer feedback in the collaborative writing practices could help them improve the quality of their text. It is in line with the study conducted by Ebadi and Rahimi (2017) which reported that peer editing or peer feedback practices through Google Docs help the students improve their writing skills. The use of Google Docs benefited the students with the opportunity to work and think precisely in a sufficient amount of time and proper place (at home) (Ebadi \& Rahimi, 2017; Suwantarathip \& Wichadee, 2014).

Moreover, this activity contributed to the students' increased awareness about errors they made on the text and at the same time they had opportunities to learn from others' mistakes. In relation to this matter, Rollinson (2005) explained that peer feedback enhances the students' abilities to evaluate their work and be more critical in revising their work.

\subsection{Peer Feedback Practices using GoogleDocs}

This section presents the results of the analysis of types and the occurrences of peer feedback provided by the participant students (see Table 3).

Table 3. The Occurrence of Students' Feedback

\begin{tabular}{|c|c|c|c|c|c|}
\hline \multirow{3}{*}{$\begin{array}{c}\text { Type of } \\
\text { Feedback }\end{array}$} & \multicolumn{3}{|c|}{ Students' Group } & \multirow{3}{*}{ Total } & \multirow{3}{*}{$\%$} \\
\hline & \multicolumn{3}{|c|}{$\overline{\text { Group Group Group }}$} & & \\
\hline & A & B & C & & \\
\hline \multicolumn{6}{|l|}{ Direct } \\
\hline \multicolumn{6}{|l|}{ Feedback } \\
\hline Insertion & - & 2 & - & 2 & $8 \%$ \\
\hline Substitution & 12 & 2 & 7 & 21 & $92 \%$ \\
\hline Deletion & - & - & - & - & - \\
\hline Reformulation & - & - & - & - & - \\
\hline \multicolumn{6}{|l|}{ Indirect } \\
\hline \multicolumn{6}{|l|}{ Feedback } \\
\hline Coded & - & - & - & - & - \\
\hline Uncoded & - & - & - & - & - \\
\hline Commentary & - & - & - & - & - \\
\hline Instruction & - & - & - & - & - \\
\hline Total & 12 & 4 & 7 & 23 & $100 \%$ \\
\hline
\end{tabular}

The majority of the students $(92 \%)$ provided the feedback in the form of substitution where they replace the mistaken words and write the correct words in the comments sections. For example, one of the students in Group A replaced a typo of 'us' with 'use' in the following sentence: To reach Gunung panten the visitors 
can us a motorcycle or car... Fewer students (8\%) provided the feedback in the form of insertion. The insertion was provided when the feedback aimed to add complementary words in a sentence considered incomplete. For example, the student in group 2 inserted a subject in a sentence without a subject.

Table 4. The Occurrence of Students' Feedback on Writing Aspects

\begin{tabular}{lccccc}
\hline \multirow{2}{*}{$\begin{array}{l}\text { Writing } \\
\text { Aspect }\end{array}$} & \multicolumn{3}{c}{ Students' Group } & & \\
\cline { 2 - 4 } & Group & Group & Group & Total & $\%$ \\
\hline Content & A & B & C & & \\
Organization & - & - & - & - & - \\
Vocabulary & - & - & - & - & - \\
Language Use & - & 3 & 5 & 8 & $35 \%$ \\
Mechanics & 12 & 1 & 2 & 15 & $65 \%$ \\
Total & 12 & 4 & 7 & 23 & $100 \%$ \\
\hline
\end{tabular}

Table 4 displays the occurrences of students' feedback on particular writing aspects. It is noticeable that the students' feedback focused more on the mechanics $(65 \%)$, followed by the language use $(35 \%)$. As far as the mechanics aspect is concerned, the students' feedback focused on the spelling errors, punctuation, and capitalization. For example, the identified spelling errors covered the words 'existence', 'satisfied', 'place', and 'use'. As for the language use, the students identified errors related to subject-verb agreement and tenses. For example, one of the students in Group $\mathrm{C}$ provided feedback on the following sentence: The facility that are usually served in this place are natural pools that have hidden properties... The student highlighted the word 'facility' that does not match the verb 'are' that typically requires a subject with a 'plural' noun. As a result, the group changed the word 'facility' to 'facilities'. In sum, the students' feedback on grammar and mechanics indicates that their confidence in commenting on other aspects was low. This might be attributed to their low level of proficiency (Guenette, 2007) as well as their hesitation to critique other students' work (Tai et al., 2015). For that reason, a number of studies have revealed that students in their study preferred to receive feedback from their teacher to their peers'. As Tsui and $\mathrm{Ng}$ (2000) reported, the students believed that the one who is qualified to provide a proper comment for them is the teachers because the teachers give more specific comments, explain more clearly what the problems are, and provide more concrete suggestions for revision. In a similar vein, Tai et al (2015) stated that most students in their study mentioned that teachers' feedback is more essential for their performance because it can identify the writing errors and weaknesses accurately and supply alternative ways of expressing some phrases. Therefore, utilizing the peer feedback practices in both ESL and EFL classrooms should be supplemented by the teachers' feedback (Tsui and $\mathrm{Ng}, 2000$ ).

\section{CONCLUSIONS}

The results of the study indicated that with several features offered by Google Docs could facilitate the students to generate the ideas, organize the text structure, and construct the sentences collaboratively online. It was noticeable that the students used the chat room feature as a platform to communicate with each other and provided feedback through the comment feature. This finding resonates with that of Suwantarathip and Wichadee's (2014) study that special features on Google Docs supported the students to learn more effectively. The result is also in line with Yeh and Chen's (2019) study that Google Docs allowed the students to work collaboratively in producing a single paper. In sum, the current study recommends the use of Google Docs for the students to work collaboratively, particularly during the time where face-to-face meetings are restricted.

\section{REFERENCES}

Alharbi, M. A. (2019). Exploring the potential of Google Docs in facilitating innovative teaching and learning practices in an EFL writing course. Innovation in Language Learning and Teaching, 14(2), 1-16.

Alsubaie, J., \& Ashuraidah, A. (2017). Exploring writing individually and collaboratively using google docs in EFL contexts. English Language Teaching, 10(10), 10-30.

Alwasilah, A. C. (2001). Language, culture, and education: A portrait of temporary of Indonesia. Bandung: Andira.

Bijami, M., Kashef, S. H., \& Nejad, S. M. (2013). Peer feedback in learning English writing: Advantages and disadvantages. Journal of Studies in Education, 3(4), 91-97.

Bitchener, J., \& Ferris, D. R. (2012). Written corrective feedback in second language acquisition and writing. New York: Routledge.

Burns, A. (2007). Action Research. In J. Cummins, \& C. Davison, International of handbook of English language teaching (pp. 987-1002). Boston, MA: Springer.

Chen, T. (2014). Technology-supported peer feedback in ESL/EFL writing classes: A research synthesis. Computer Assisted Language Learning, 29(2), 133.

Creswell, J. W. (2012). Educational research: Planning, conducting, and evaluating quantitative and qualitative research. Boston: Pearson. 
Dastgeer, G., \& Afzal, M. T. (2015). Improving English writing skill: A case of problem based learning. American Journal of Educational Research, 3(10), 1315-1319.

Deveci, T. (2018). Student perceptions on collaborative writing in a project-based course. Universal Journal of Educational Research, 6(4), 721-732.

Dobao, A. F., \& Blum, A. (2013). Collaborative writing in pairs and small groups: Learners' attitudes and perceptions. System, 41(2), 365-378.

Ebadi, S., \& Rahimi, M. (2017). Exploring the impact of online peer-editing using Google Docs on EFL learners' academic writing skills: a mixed methods study. Computer Assisted Language Learning, 30(8), 787-815.

Farrah, M. (2012). The impact of peer feedback on improving the writing skills among Hebron university students. An-Najah University Journal for Research (Humanities), 26(1), 179-210.

Fung, Y. M. (2010). Collaborative writing features. RELC Journal, 41(1), 18-30.

Google Support. (2020). Get started with sheet: share and collaborate on files or share files with larger groups of people. Google Workspace Learning Center.

(https://support.google.com/a/users/answer/930598 7\#3.5) accessed June 2020).

Guénette, D. (2007). Is feedback pedagogically correct? Research design issues in studies of feedback on writing. Journal of Second Language Writing, 16(1), 40-53.

Hadjerrouit, S. (2011). A collaborative writing approach to Wikis: Design, implementation, and evaluation. Issues in Informing Science and Information Technology, 8, 431-449.

Howard, R. M. (2001). Collaborative pedagogy. In G. Tate, A. Rupiper, \& K. Schick, A guide to composition pedagogies (pp. 54-70). Oxford: Oxford University Press.

Hyland, K., \& Hyland, F. (2006). Feedback on second language students' writing. Language Teaching, 39(02), 83-101.

Ishtaiwa, F. F., \& Aburezeq, I. M. (2015). The impact of Google Docs on student collaboration: A UAE case study. Learning, Culture and Social Interaction, 7, 85-96.

Janssen, J., Erkens, G., Kirschner, P. A., \& Kanselaar, G. (2012). Task-related and social regulation during online collaborative learning. Metacognition and Learning, 7(1), 25-43.
Khalil, E. (2018). The efficacy of peer feedback in Turkish EFL students' writing performance. Journal of Literature and Art Studies, 8(6), 920931.

Li, M., \& Zhu, W. (2017). Good or bad collaborative wiki writing: Exploring links between group interactions and writing products. Journal of Second Language Writing, 35, 38-53.

Limbu, L., \& Markauskaite, L. (2015). How do learners experience joint writing: University students' conceptions of online collaborative writing tasks and environments. Computers \& Education, 82(32), 393-408

Metilia, T., \& Fitrawati. (2018). Using Google Docs for collaborative writing in teaching writing descriptive text to English departement students. Journal of English Language Teaching, 7(1), 194200.

Min, H. T. (2005). Training students to become successful peer reviewers. System, 33(2), 293-308.

Mulligan, C., \& Garofalo, R. (2011). A collaborative writing approach: Methodology and student assessment. The Language Teacher, 35(3), 5-10.

Nykopp, M., Marttunen, M., \& Erkens, G. (2018). Coordinating collaborative writing in online environment. Journal of Computing in Higher Education, 31(3), 536-556.

Rollinson, P. (2005). Using peer feedback in the ESL writing class. ELT Journal, 59(1).

Sadler, D. R. (1989). Formative assessment and the design of instructional systems. Instructional Science, 18, 119-144.

Sadler, G. R. (2010). Recruitment of hard-to-reach population subgroups via adaptations of the snowball sampling strategy. Nursing and Health Sciences, 12(3), 369-374.

Shehadeh, A. (2011). Effects and students perceptions of collaborative writing in L2. Journal of Second Language Writing, 20(4), 286-305.

Storch, N. (2005). Collaborative writing: product, process, and students' reflection. Journal of Second Language Writing, 14, 153-173.

Storch, N. (2011). Collaborative writing in L2 contexts: processes, outcomes, and future directions. Annual Review of Applied Linguistics, 31, 275-288.

Storch, N. (2013). Collaborative writing in L2 classrooms. Bristol, UK: Multilingual Matters.

Stringer, E. T. (2014). Action research. Thousand Oaks, California: SAGE Publications. 
Suwantarathip, O., \& Wichadee, S. (2014). The effects of collaborative writing activity using Google Docs on students' writing abilities. The Turkish Online Journal of Educational Technology, 13(2), 148-156.

Tai, H.-C., Lin, W.-C., \& Yang, S. C. (2015). Exploring the effects of peer review and teachers' corrective feedback on EFL students' online writing performance. Journal of Education Computing, 53(2), 284-309.

Thompson, J. (2008). Don't be afraid to explore Web 2.0. Education Digest, 89(10), 711-778.

Tsui, A. B., \& Ng, M. (2000). Do secondary L2 writers benefit from peer comments? Journal of Second Language Writing, 9(2), 147-170.

Wahyuni, E. (2018). Teaching English with an internetbased nature of Google Docs to improve students' critical thinking. International Journal of Education, 10(2), 149-161.

Wakabayashi, R. (2016). The effects of the peer feedback process on reviewers' own writing. English Language Teaching, 6(9), 177-192.

Weigle, S. C. (2002). Assessing writing. Cambridge, UK: Cambridge University Press.

Widarsih, S., \& Suherdi, D. (2019). Analisis umpan balik tertulis guru pada tulisan siswa dalam teks recount. Jurnal Penelitian Pendidikan, 19(3), 434444.

Widodo, H. P. (2013). Implementing collaborative process based writing in the EFL college classroom. Research Papers in Language Teaching and Learning, 4(1), 198-206.

Wigglesworth, G., \& Storch, N. (2012). What role for collaboration in writing and writing feedback? Journal of Second Language Writing, 21(4), 364374.

World Health Organization. (2020). Considerations in adjusting public health and social measures in the context of COVID-19: Interim guidance, 16 April 2020. World Health Organization. (https://apps.who.int/iris/handle/10665/331773 accessed 5 May 2020).

Yeh, Shiou-Wen., \& Chen, Cheng-Ting. (2019). EFL learners' peer negotiation and attitudes in mobileassisted collaborative writing. Language Education \& Assessment, 2(1), 41-56.

Younes, Z. B., \& Albalawi, F. S. (2015). Exploring the most common types of writing problems among English language and translation major sophomore female students at Tabuk University. Asian Journal of Basic and Applied Sciences, 3(2), 7-26.

Yu, S., \& Lee, I. (2015). Understanding EFL students' participation in group peer feedback of L2 writing: A case study from an activity theory perspective. Language Teaching Research, 19(5), 572-593.

Zhang, M. (2018). Collaborative writing in the EFL classroom: The effects of L1 and L2 use. System, $76,1-12$. 